\title{
FREE TROPOSPHERIC AEROSOLS OVER SOUTH AFRICA
}

\author{
Giannakaki Elina $^{1 *}$, Anne Pfüller ${ }^{1}, K^{2}$ mo Korhonen ${ }^{1,2}$, Tero Mielonen ${ }^{1}$, Lauri Laakso ${ }^{3,4}$, Ville \\ Vakkari $^{3}$, Holger Baars ${ }^{5}$, Ronny Engelmann ${ }^{5}$, Johan P. Beukes ${ }^{4}$, Pieter G. Van Zyl ${ }^{4}$, Miroslav \\ Josipovic $^{4}$, Petri Tiitta ${ }^{4,6}$, Kgaugelo Chiloane ${ }^{4}$, Stuart Piketh ${ }^{4}$, Heikki Lihavainen ${ }^{3}$, Kari Lehtinen ${ }^{1,2}$ \\ ${ }^{1}$ Finnish Meteorological Institute, FI-70211, Kuopio, Finland, *Email: eleni.giannakaki@fmi.fi \\ ${ }^{2}$ Department of Applied Physics, University of Eastern Finland, FI-70211 Kuopio, Finland \\ ${ }^{3}$ Finnish Meteorological Institute, FI-00101, Helsinki, Finland \\ ${ }^{4}$ Unit for Environmental Sciences and Management, North-West University, Potchefstroom, South Africa \\ ${ }^{5}$ Leibniz Institute for Tropospheric Research, Permoserstrasse 15, D-04318, Leipzig, Germany \\ ${ }^{6}$ Department of Environmental Sciences, University of Eastern Finland, FI-70211 Kuopio, Finland
}

\begin{abstract}
Raman lidar data of one year was been analyzed to obtain information relating aerosol layers in the free troposphere over South Africa, Elandsfontein. In total, 375 layers were observed above the boundary layer during the period $30^{\text {th }}$ January $2010-31^{\text {st }}$ January 2011. The seasonal behavior of aerosol layer geometrical characteristics as well as intensive and extensive optical properties were studied. In general, layers were observed at higher altitudes during spring $(2520 \pm 970 \mathrm{~m})$ while the geometrical layer depth did not show any significant seasonal dependence. The variations of most of the intensive and extensive optical properties analyzed were high during all seasons. Layers were observed at mean altitude of 2100 $\mathrm{m} \pm 1000 \mathrm{~m}$ with lidar ratio at $355 \mathrm{~nm}$ of $67 \pm 25$ and extinction-related Ångström exponent between 355 and $532 \mathrm{~nm}$ of $1.9 \pm 0.8$.
\end{abstract}

\section{INTRODUCTION}

Atmospheric aerosols have a strong impact on radiative forcing, chemical processes in the atmosphere, cloud properties and air quality [1]. Despite their importance in atmospheric physics, significant gaps in the scientific knowledge about aerosols still exist. In particular, the vertical distribution of aerosols is not well known, but of essential relevance to understanding aerosol effects on climate [2]. Thus, systematic observations of aerosol optical properties are needed.

In South Africa, only few measurements of aerosol vertical profiles have been carried out, and most of the available data is from short field campaigns. Previous studies have indicated that
South Africa is one of the most affected countries in the world with regard to aerosol load, due to various natural and anthropogenic activities [e.g. 3].

Considering the above mentioned, systematic observations of the optical properties of aerosol vertical profiles at acceptable accuracy are needed.

The measurements presented in this paper were performed within the framework of the EUCAARI project [4]. One year of Raman lidar observations over South Africa are presented in terms of geometrical and optical aerosol characteristics.

\section{METHODOLOGY}

\subsection{Research site}

The lidar measurement site was located on a hill top at Elandsfontein $\left(26^{\circ} 15^{\prime} \mathrm{S}, 2^{\circ} 26^{\prime} \mathrm{E}, 1745 \mathrm{~m}\right.$ a.s.1.) in the Highveld region of South Africa. The station was located approximately $150 \mathrm{~km}$ east from the Johannesburg-Pretoria megacity, which is the largest metropolitan area in South Africa with a population of over 10 million people.

One significant source of atmospheric pollutants in the region is biomass burning through wild and agricultural fires. In addition, the burning of solid fuels such as coal, wood, dung and residual crops for domestic cooking and space heating is also an important source of emissions into the atmosphere in southern Africa. These emissions (from wild fires and domestic burning) are difficult to 
distinguish from one another when they are transported above the boundary layer.

Another source of aerosols in the region investigated is anthropogenic emissions from industrialized regions in South Africa. The major industrial pollution sources within a $50 \mathrm{~km}$ radius of the measurement site include ten coal-fired power plants, a petrochemical plant and some metallurgical plants [5].

Dust from Botswana and Namibia might also be possible sources of aerosols in this region. The shortest distance to the Indian Ocean is approximately $350 \mathrm{~km}$, therefore marine air masses can also have an impact on atmospheric aerosols at Elandsfontein.

\subsection{Multi-wavelength lidar Polly ${ }^{\mathrm{XT}}$}

The transportable aerosol Raman lidar Polly ${ }^{\mathrm{XT}}$ was operated remotely at Elandsfontain in South Africa.

The range-resolved backscatter signal of elastic lidar contains information that can be used to derive the height of aerosol layers. The gradient method was applied to determine the bottom and top layer heights of the aerosols in the free troposphere. Planetary boundary layer top heights were retrieved from the lidar backscatter signal at $1064 \mathrm{~nm}$ using the Wavelet Covariance Transform method.

Extinction and the backscatter coefficient profiles at 355 and $532 \mathrm{~nm}$ have been obtained with the Raman method [6], while the backscatter at 1064 $\mathrm{nm}$ has been determined using the Klett method [7].

\section{RESULTS}

The percentage of the night-time measurements performed each month in terms of hourly averaged profiles every three hours is presented in Figure 1(a) (blue bars), and varies between 3 and $72 \%$ for all the months. Measurement analysis was not performed during the presence of low clouds and rain (shaded bars) or due to the scheduled shutdowns (grey bars). The percentage of the measurements in which at least one freetropospheric aerosol layer was observed (green bars) is shown in Figure 1(b). In total, 375 aerosol layers were observed above the boundary layer during the period studied.

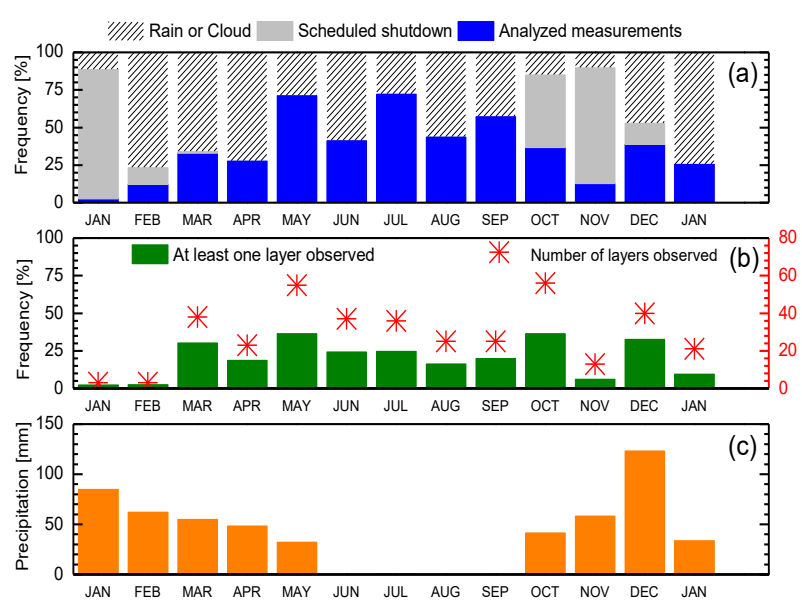

Figure 1. (a) Percentage of night-time analyzed measurements, scheduled shutdown and unanalyzed measurements due to weather conditions; (b) the percentage of measurements in which free tropospheric aerosol layers were observed (green bars) and the total number of the observed layers (red stars) per month; (c) monthly accumulated precipitation at Elandsfontein.

The total number of the observed layers per month is presented with red stars in the same figure.

Approximately $90 \%$ of the annual precipitation falls during the wet season (October - March) [5], as indicated in Figure 1 (c). Fewer measurements were performed during the wet period. The seasonal precipitation cycle should not only affect the number of measurements that could be performed but also the total number of layers observed. Therefore it is expected that the fraction of measurements of free-tropospheric aerosol layers in relation to the total number of observations should be less during the wet season due to wet scavenging.

However, our results indicate that during the wet period a relatively large number of layers are still observed in the free troposphere. The general anticyclonic nature of atmospheric circulation over the region, results in the formation of stable layers of air throughout the year [8].

Our complete dataset of lidar measurements in terms of geometrical characteristics is shown in Figure 2. 


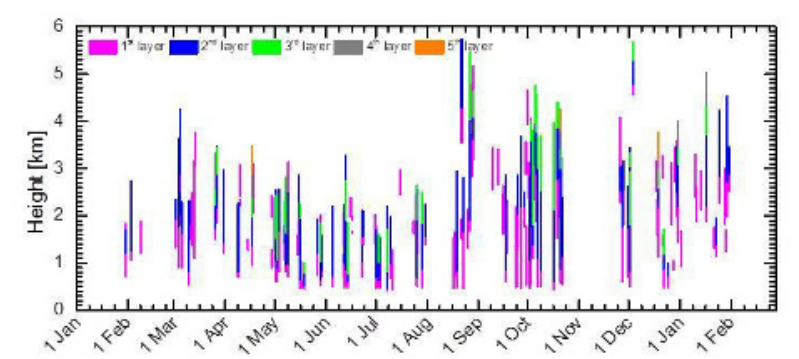

Figure 2. Geometrical boundaries of free tropospheric aerosol layers observed between $30^{\text {th }}$ January 2010 and $31^{\text {st }}$ January 2011.

The vertical lines present the observed height ranges of free tropospheric aerosol layers. Out of 429 hourly analyzed lidar observation, we observe free tropospheric pollution events on 223 hours (i.e. $52 \%$ ). In total 375 free tropospheric aerosol layers were observed. The geometrical depth of the free tropospheric layers varies from a few hundred meters to several kilometers throughout the period under investigation. Pollution events are observed as single layer on $52 \%$ of the cases, while they are often characterized by two (32\%), three $(13 \%)$ or more particle layers $(3 \%)$.

The seasonal frequency distribution plots for the lidar ratio at $355 \mathrm{~nm}$ and the Ångström exponent related to extinction between 355 and $532 \mathrm{~nm}$ are presented in Figure 3 and 4, respectively. An average lidar ratio of $67 \pm 25 \mathrm{sr}$ at $355 \mathrm{~nm}$ and a mean extinction-related Ångström exponent of 1.9 \pm 0.8 between 355 and $532 \mathrm{~nm}$ are measured during the entire sampling period in South Africa.

Between late winter (Jun. - Aug.) and throughout spring (Sep. - Nov.) high lidar ratios are observed. During this period a significant contribution of aerosol layers originates from wild and controlled fires. Although these fire plumes occur at ground level, they are lifted higher in the atmosphere due to the increased heat and may be transported above Elandsfontein. Domestic biomass burning in informal settlements for cooking and heating can also contribute, but these emissions are exclusively emitted at ground level. It is therefore unlikely that such emission close to Elandsfontein will have a significant impact to free tropospheric aerosol load measured. However, household emissions are common across the entire southern Africa, which implies that regional transport of such emission further away from Elandsfontein may results in a contribution to the free tropospheric load measured over Elandsfontein. The absorbing smoke aerosols, originating from all the aforementioned combustion sources, can explain the large lidar ratio values observed.
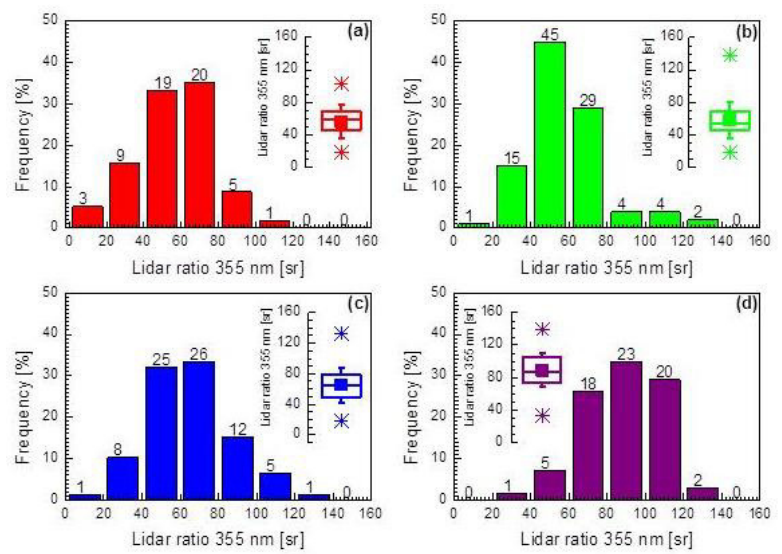

Figure 3. Frequency distribution of lidar ratio at 355 $\mathrm{nm}$ of free tropospheric aerosol layers in South Africa between $30^{\text {th }}$ January 2010 and $31^{\text {st }}$ January 2011, for (a) summer, (b) autumn, (c) winter and (d) spring. Box and whisker plots are also presented for each of the seasons: filled square is the mean value, horizontal line is the median, boxes are the 25 and $75 \%$ percentiles respectively, whiskers represent the one standard deviation and stars the minimum and maximum values.
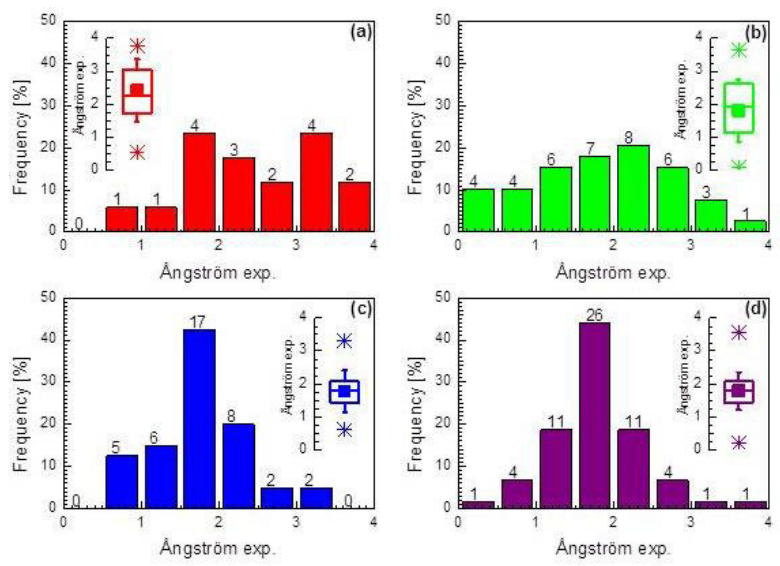

Figure 4. The same as Figure 3 but for Ångström exponent.

Larger Ångström exponents were observed during summer (Dec. - Feb.). One possible explanation is the removal of larger aerosols through wetscavenging during these wetter months. Most of the free-tropospheric aerosol layers observed during this period were associated with an easterly air mass flow. The major industrial pollution 
sources are located primarily either to the north, west or southwest of the lidar at Elandsfontein (Laakso et al., 2012). Therefore, the easterly flow that prevails during summer results in a less polluted free troposphere, compared to other seasons. Aerosols measured during this period could also include maritime aerosols with air masses moving from the Indian Ocean.

\section{CONCLUSIONS}

Geometrical characteristics and optical properties of elevated aerosol layers at a continental site in South Africa are presented. During winter nights layers are observed up to $3000 \mathrm{~m}$. These aerosol layers are probably trapped between the inversion surface layer and an absolutely stable layer that is formed in $90 \%$ of days during winter [8]. Aerosol layers are more frequently observed during biomass burning period and are determined to be at higher heights.

Except for the intensive biomass burning period the lidar ratios and Ångström exponents are within the range of previous observations for urban/industrial aerosols $[9,10]$. Considering that the Elandsfontein measurement station is located in the midst of large industrial plants this is reasonable. However, we observed large variability in both intensive and extensive aerosol properties of free tropospheric aerosol layers. From August to October, the lidar ratio of elevated layers is high, on average $83 \mathrm{sr}$, which is comparable to biomass burning smoke $[10,11]$. Mean Ångström exponent related to extinction was found to be 1.8 both for dry and biomass burning period indicating the same size of particles for both biomass burning and (industry originated) polluted aerosols.

\section{ACKNOWLEDGEMENT}

This work has been partly supported by the European Commission $6^{\text {th }}$ Framework program under the EUCAARI. Elina Giannakaki acknowledges the support of the Academy of Finland. The authors acknowledge the staff of the North-West University for valuable assistance and routine maintenance of the lidar. We also acknowledge Eskom and Sasol for their logistical support for measurements at Elandsfontein.

\section{REFERENCES}

[1] Ramanathan V., P. J. Crutzen, J.T. Kiehl, D. Rosenfeld, 2001: Aerosols, climate, and the hydrological cycle, Science, 294, pp. 2119-2124.

[2] Kaufman Y. J., O. Tanre, O. Boucher, 2002: A satellite view of aerosols in the climate system, Nature, 419, pp. 215-223.

[3] Piketh S. J., R.J. Swap, W. Maenhaut, H.J. Annegarn, P. Formenti, 2002: Chemical evidence of long-range atmospheric transport over southern Africa, J. Geophys. Res., 107, pp. 4817.

[4] Kulmala, M., et al., 2011: General overview: European Integrated project on Aerosol Cloud Climate and Air Quality interactions (EUCAARI) integrating aerosol research from nano to global scales, Atmos. Chem. Phys., 11, pp. 13061-13143.

[5] Laakso L., V. Vakkari, A. Virkkula, et al. 2012: South African EUCAARI measurements: seasonal variation of trace gases and aerosol optical properties, Atmos. Chem. Phys., 12, pp. 1847-1864.

[6] Ansmann A., U. Wandinger, M. Riebesell, C. Weitkamp, W. Michaelis, 1992: Independent measurement of extinction and backscatter profiles in cirrus clouds by using a combined Raman elasticbackscatter lidar, Appl. Optics, 31, pp. 7113-7131.

[7] Klett J.D., 1981: Stable analytical inversion solution for processing lidar returns, Appl. Optics, 20, pp. 211-220.

[8] Cosijn, C., P. D Tyson, 1996: Stable discontinuities in the atmosphere over South Africa, S. Afr. J. Sci., 92, pp. 381-386.

[9] Müller, D., A. Ansmann, I. Mattis, M. Tesche, U. Wandinger, D. Althausen, G. Pisani, 2007: Aerosoltype-dependent lidar ratios observed with Raman lidar, J. Geophys. Res., 112, D16202.

[10] Giannakaki, E., D. S. Balis, V. Amiridis, C. Zerefos, 2010: Optical properties of different aerosol types: seven years of combined Raman-elastic backscatter lidar measurements in Thessaloniki, Greece, Atmos. Meas. Tech., 3, pp. 569-578.

[11] Amiridis V., D.S. Balis, E. Giannakaki, A.Stohl,, S. Kazadzis, M.E. Koukouli, P. Zanis, 2009: Optical characteristics of biomass burning aerosols over Southeastern Europe determined from UV-Raman lidar measurements, Atmos. Chem. Phys., 9, pp. 2431-2440. 